\title{
Poéticas em conflito: a literatura brasileira traduzida por Elizabeth Bishop no contexto das trocas culturais Brasil x EUA
}

\author{
Eduardo Luis Araújo de Oliveira Batista *
}

\begin{abstract}
This article proposes to analyse, from a systemic approach of cultural exchanges between different nations and languages, the Brazilian translation work of American poet Elizabeth Bishop, produced in the 1950-70's. Based on the polysystem theory of Itamar Even-Zohar, and Andrè Lefevere's theory of rewriting, we demonstrate how the flow of literary translations often follows dynamics that go beyond strictly literary criteria. Bishop's view of Brazilian literature is traced through the study of her translations and other textual production and it shows a cultural conflict. This conflict is found in the contact of two different literary poetics and two different modernist proposals: the Anglo-Saxon tradition in which Bishop developed her literary career, and the Brazilian literature, until then affiliate to French literary tradition. It is appointed in this article that this tension is a consequence of this specific historical moment, when two central literary systems dispute over one considered peripheral.
\end{abstract}

Keywords: Elizabeth Bishop; literaly translation; Brazilian modernism; polysystem theory.

Resumo: Neste artigo propomos analisar a obra tradutória brasileira da poeta norteamericana Elizabeth Bishop, realizada nas décadas de 1950-70, a partir de uma visão sistêmica das trocas culturais entre diferentes nações e línguas. Baseando-nos na teoria dos polissistemas de Itamar Even-Zohar e na teoria da reescrita de André Lefevere, mostramos como o fluxo de traduções literárias muitas vezes obedecem a dinâmicas que vão além de critérios estritamente literários. Identificamos na leitura que Bishop fez da literatura brasileira, por meio do estudo de suas traduções e outras produções textuais, uma tensão entre duas diferentes poéticas literárias e duas diferentes propostas modernistas, a da tradição em língua inglesa, da qual Bishop é insigne representante, e a brasileira, até aquele momento histórico afiliada à

\footnotetext{
* Doutor em Teoria e História da Literatura pela UNICAMP, pós-doutorando na ECA/USP. Email: eduardolaob@yahoo.com.br.
} 
tradição francesa. Essa tensão é vista como reflexo de um momento de disputa entre dois sistemas literários centrais sobre um sistema considerado então periférico.

Palavras-chave: Elizabeth Bishop; tradução literária; Modernismo brasileiro; teoria dos polissistemas. 
Batista, E. L. A. O. - Poéticas em conflito: a literatura brasileira traduzida por Elizabeth Bishop no contexto das trocas culturais Brasil x EUA

Em sua teoria da reescrita, na qual aborda o poder de mediação e criação de imagens culturais presentes na tradução, André Lefevere utiliza 0 conceito de sistema literário, introduzido nos Estudos da Tradução pelo estudioso Itamar Even-Zohar. Lefevere define sistema "como um termo neutro, descritivo, usado para designar um grupo de elementos interrelacionados que compartilham certas características que os separam daqueles vistos como não pertencentes ao sistema" (LefEVERE 1992: 12) ${ }^{1}$. 0 conceito de sistema é empregado por permitir uma abordagem funcional em que a literatura é vista em correlação a língua, sociedade, economia, política, ideologia etc. Isso ocorre por ser a literatura autorregulada e ao mesmo tempo condicionada por outros sistemas. Segundo Zohar, "qualquer sistema semiótico (tal como a literatura ou a língua) é apenas um componente de um (poli)sistema maior - o da 'cultura', ao qual é subjugado e com o qual é isomórfico [...]" (ZoHAR 1990: 2). O polissistema da cultura "pode ser concebido como um componente em um mega (poli)sistema, i.e., aquele que organiza e controla várias comunidades" (Ibidem: 24). Os diversos polissistemas culturais se articulam em uma hierarquia em que não há apenas um centro, mas diversos centros e periferias. Segundo Zohar, essa hierarquia entre os polissistemas determina em grande parte a dinâmica das trocas culturais, nas quais se incluem as traduções, que formam, por sua vez, um dos subsistemas mais ativos do sistema literário.

Para Lefevere, as reescritas, principalmente as traduções, afetam profundamente a interpenetração dos sistemas literários, não apenas por projetar a imagem de um escritor ou obra em outra literatura, ou por não conseguir fazê-lo, mas pela possibilidade de introduzir novas estratégias em uma poética e preparar o caminho para alterações na mesma. Segundo a teoria dos polissistemas, alguns sistemas literários ocupariam uma posição de centralidade por possuírem uma literatura considerada forte, autossuficiente,

\footnotetext{
${ }^{1}$ Esta e outras citações do artigo, originalmente em inglês, foram traduzidas pelo autor deste artigo.
} 
Batista, E. L. A. O. - Poéticas em conflito: a literatura brasileira traduzida por Elizabeth Bishop no contexto das trocas culturais Brasil x EUA

capaz de responder por si própria às suas demandas internas, enquanto os sistemas periféricos necessitariam regular suas deficiências através do empréstimo de modelos dos sistemas centrais. A partir dessa abordagem funcional, os textos só constituem um fator dinâmico nas relações sistêmicas em função de sua representatividade como modelos. Em função dessa perspectiva as traduções são classificadas como primárias, quando representam novos modelos e trazem inovações ao sistema receptor; ou secundárias, quando não trazem inovação e são consideradas conservadoras.

Nesse contexto, o sistema literário brasileiro pode ser considerado periférico em boa parte de sua trajetória histórica, devido ao seu reduzido relevo internacional, e por ter se mantido em relação de dependência junto aos sistemas centrais ocidentais, norte-americano e europeus, durante seu processo de formação. Apesar dessa relação de dependência, como situa Zohar, ser típica da "juventude" de um sistema, ela pode se prolongar por razões que vão além do estado do sistema literário como tal (ou seja, de sua maturidade). Segundo Zohar, a tradução de obras de uma literatura periférica para uma central não ofereceria inovações e seria moldada às normas já estabelecidas no sistema receptor. Ela seria considerada como uma tradução secundária. Como dissemos anteriormente, isso ocorreria em função do sistema central ser considerado autossuficiente e não necessitar da influência de modelos externos. Neste caso, a tradução não responderia às necessidades do sistema literário, mas de outros sistemas, como político ou econômico. É o que acreditamos ter ocorrido durante as décadas de 1950-60 nos EUA com relação à América Latina, em que a disputa de influências ensejada pela Guerra Fria gerou um intenso programa de intercâmbio cultural no qual se incluía o financiamento de projetos de tradução. Como atesta Heloísa Barbosa,

[...] no caso das traduções de obras literárias brasileiras e ficção em prosa para a língua inglesa, o maior patrocinador parece ter sido o governo norte-americano, que desejou promover comunicação 
Batista, E. L. A. O. - Poéticas em conflito: a literatura brasileira traduzida por Elizabeth Bishop no contexto das trocas culturais Brasil x EUA

intercultural em função de promover a amizade entre as nações do continente americano [...]. Entretanto, o governo norte-americano não parece ter selecionado diretamente os textos para tradução, ou contratado tradutores para realizar as traduções. Esse trabalho parece ter sido assumido pelos experts das agências que forneceram os fundos (tais como as fundações Rockfeller e Ford) (BARBOSA 1994: 104-105).

Não houve por parte do sistema literário norte-americano um movimento de interesse pelos textos (enquanto modelos poéticos) latinoamericanos, mas um interesse político, que gerou uma demanda no sistema cultural. O resultado disso é que apesar do boom tradutório da literatura latino-americana nos anos 1960 nos Estados Unidos (no qual se incluiu o Brasil $^{2}$ ), não se pode falar de uma influência daquela no sistema literário norte-americano. É o que demonstra a avaliação de Barbosa sobre a recepção do Modernismo brasileiro nos países de língua inglesa:

[...] apenas duas das obras traduzidas no período [décadas de 1920-30]
foram obras produzidas por escritores relacionados ao movimento
Modernista: "Urupês", de Monteiro Lobato (1918, "Brazilian short
stories", 1925), e "Amar, Verbo Intransitivo", de Mário de Andrade
(1927, "Fraulein", 1932), além de não serem obras significativas no
movimento. "Macunaíma", por exemplo, não foi publicado em língua
inglesa antes de 1984. Esses fatos se colocam contra a existência de
um maior interesse pela expressão literária do movimento Modernista
brasileiro de parte do mundo falante da língua inglesa (BARBOSA 1994:
32).

Talvez, o realismo-fantástico pudesse ser considerado como um elemento da poética latino-americana que foi exportado à época. Barbosa, no entanto, sugere que o boom da literatura realista-fantástica tenha sido acima de tudo um fenômeno tradutório, encontrando sua origem antes na reescrita efetuada pelos tradutores e críticos estrangeiros do que em um movimento literário criado e exportado pelos escritores latino-americanos:

\footnotetext{
2 Segundo Barbosa, o número de obras literárias brasileiras traduzidas para o inglês quase triplicou nos anos 1960 (BARBOSA 1994: 44).
} 
Batista, E. L. A. O. - Poéticas em conflito: a literatura brasileira traduzida por Elizabeth Bishop no contexto das trocas culturais Brasil x EUA

[...] sendo este o caso, o boom seria aqui visto como algo vindo de fora, não algo gerado no espaço chamado "América Latina". Consequentemente, não é possível ver o boom como se iniciando na publicação de obras originais em espanhol. A visão tomada aqui é de que o boom é antes de tudo um fenômeno de tradução (BARBOSA 1994: 40).

O boom literário latino-americano estaria vinculado a um crescimento do mercado ocidental para seus produtos culturais, aliado aos interesses políticos já descritos. A restrita abertura do sistema literário norte-americano a modelos literários estrangeiros, especificamente os dos sistemas literários considerados periféricos, pode ser confirmada pela tradição norte-americana na abordagem tradutória, que Lawrence VENUTI (1995) caracteriza como conservadora e dominada pela estratégia "domesticadora", transformando-as nas traduções secundárias de que fala Zohar. Essa estratégia resulta em traduções como as feitas pela poeta Elizabeth Bishop nos anos 1950-70, que assimilam e apagam a originalidade dos textos, diluindo sua capacidade de influenciar o sistema receptor, como apontado em artigo anteriormente publicado (BATISTA 2005). Essa estratégia se justificaria não por uma intrínseca "inferioridade" do texto periférico, mas pelas relações dos sistemas literários, determinadas por suas respectivas posições hierárquicas e pela tentativa de imposição de uma poética sobre outra, tendência a acontecer quando uma literatura central traduz uma periférica. Em um movimento contrário - na tradução de um texto de uma literatura central para uma periférica - a abordagem é inversa e o alto status da obra (em parte devido ao status do seu sistema de origem) leva a uma tradução cuidadosa no sentido de preservar no texto as características do que é considerado como sua originalidade (ou seja, aquilo que distingue sua poética daquela em vigor no sistema receptor). Neste caso, a tradução é orientada para o sistema de origem, em uma tentativa de preservar as especificidades do texto e apresentá-lo como modelo a ser copiado. 
Batista, E. L. A. O. - Poéticas em conflito: a literatura brasileira traduzida por Elizabeth Bishop no contexto das trocas culturais Brasil x EUA

A dinâmica das trocas intersistêmicas ajuda-nos a entender a abordagem "domesticadora" de Bishop, revelada pela adoção do método literal e pela seleção de textos que encontrassem modelos já existentes na literatura em língua inglesa. Como nos diz Lefevere, a tradução de textos de um sistema periférico para um central leva o tradutor a "concentrar-se em encontrar os melhores modelos secundários prontos para o texto estrangeiro, e o resultado com frequência é uma tradução não adequada ou uma grande discrepância entre a equivalência alcançada e a adequação proposta" (LefEVERE 1992: 52). São os inconvenientes do método literal na forma empregada por Bishop, que dilui os textos na tradição receptora e anula suas melhores qualidades poéticas, tornando-as assim traduções secundárias, conservadoras e incapazes de influenciar o sistema receptor. As traduções de Bishop são consideradas de baixa qualidade, em grande parte devido ao seu desconhecimento da língua portuguesa, o que a levou a erros gramaticais e semânticos. Considerando o extremo profissionalismo e dedicação que Bishop dispensava ao seu trabalho poético, em função do qual produziu uma obra reduzida, mas elogiada por sua precisão e cuidado artesanal - alguns de seus poemas levaram anos para serem concluídos, como "The Moose", que levou cerca de vinte anos -, a falta de cuidado que marcou suas traduções pode ser explicada por sua postura etnocêntrica. Apesar de seu interesse pessoal pelos autores e textos traduzidos, Bishop enxergava nossa literatura como inferior, uma cópia atrasada da literatura europeia, julgamento que se estendia de uma forma geral a toda a alta cultura brasileira, considerada uma importação de modelos estrangeiros. Seu interesse restringia-se à cultura popular, que considerava "original" e "autêntica". Provavelmente essa postura explica ter se envolvido nos projetos de tradução e antologização de nossa literatura, mesmo não se considerando totalmente apta para essas tarefas. Bishop não possuía nenhuma formação na área - literatura brasileira - e nem mesmo um conhecimento autodidata que fosse consistente. Como nossa alta literatura não Ihe interessava, não desenvolveu nenhum estudo mais sistemático do 
Batista, E. L. A. O. - Poéticas em conflito: a literatura brasileira traduzida por Elizabeth Bishop no contexto das trocas culturais Brasil x EUA

assunto e, provavelmente, além do pouco de ficção e poesia que leu (a maior parte traduzida para o inglês), não leu nenhum crítico ou historiador literário brasileiro (pelo menos não cita nenhum em suas cartas e entrevistas) ${ }^{3}$. Suas declarações são de uma pessoa com conhecimentos limitados sobre o assunto, carregadas de idiossincrasias e opiniões pessoais, pouco apropriadas a um público acadêmico, como o dos estudantes, principal alvo da antologia de poemas brasileiros que editou pela Wesleyan University em 1972. Além do interesse pessoal de Bishop pelos autores traduzidos, seu envolvimento parece explicar-se mais por razões financeiras e circunstanciais: a conjunção entre a presença de uma escritora norte-americana famosa no Brasil e o mercado que se formou à época nos Estados Unidos para produtos culturais relacionados à América Latina. Perfil que compartilha com grande parte dos tradutores de obras brasileiras para a língua inglesa, como sugere Barbosa em seu levantamento dos tradutores de nossa literatura - "aqui o maior elemento de aleatoriedade surge na pesquisa. 0 acaso parece enviar pessoas ao Brasil. 0 acaso parece levar pessoas a aprenderem português na universidade. Essas pessoas eventualmente traduzem obras brasileiras para o inglês" (BARBOSA 1994: 345).

Não se pode considerar que os textos de origem periférica não ofereçam nenhuma inovação e capacidade de influência sobre um sistema central, mas a própria postura com que tais textos são abordados impede que as possíveis inovações apareçam e sejam capazes de oferecer alguma influência, uma vez que as diferenças são negadas e apagadas, nas traduções literais e conservadoras, como as realizadas por Bishop. No caso em que estamos estudando, apesar do processo de "domesticação", acreditamos que Bishop recebeu uma influência dos textos que traduziu, como os de João

\footnotetext{
${ }^{3}$ Como afirma Paulo Henriques Britto "já nas primeiras cartas escritas aqui a poeta revela o desânimo que Ihe inspiraram a pobreza do ambiente cultural brasileiro, o provincianismo dos intelectuais locais e a falta de perspectiva do país - uma visão do Brasil que certamente não a estimulava a empreender uma imersão mais profunda na literatura brasileira" (BRITTO 1999: 17).
} 
Batista, E. L. A. O. - Poéticas em conflito: a literatura brasileira traduzida por Elizabeth Bishop no contexto das trocas culturais Brasil x EUA

Cabral de Melo Neto, que Ihe sugeriram formas poéticas (a balada para "The burglar of Babylon"), e especialmente Carlos Drummond de Andrade, que a inspirou a escrever textos com temas como memória e família (fazendo-a romper com sua poética impessoal $)^{4}$, e que também a influenciou formalmente (segundo a crítica literária Helen Vendler, Drummond Ihe teria sugerido a estrofe de três versos usada em "In the waiting room" (VENDLER 1983: 312)). Uma vez que Bishop recebeu uma influência efetiva desses autores e por ocupar um lugar de centralidade no sistema literário norteamericano, podemos considerar que apesar da estratégia "domesticadora", as traduções exerceram uma influência sobre o sistema receptor. Neste caso isso ocorreu apenas pelo fato de se conjugarem em uma mesma personagem a tradutora e uma escritora canonizada. Esta não é uma situação frequente nos Estados Unidos, diferentemente da América Latina, onde há uma tradição de escritores famosos se dedicarem à tradução de textos estrangeiros. Tal fato não deixa de possuir uma ligação direta com a dinâmica entre os sistemas centrais e periféricos que estamos analisando, na medida em que os escritores do sistema periférico se dirigem ao centro em busca de modelos, através das traduções, como o fizeram Machado de Assis (tradutor de Edgar Allan Poe), Manuel Bandeira (tradutor de Marianne Moore) e Carlos Drummond (tradutor de Guillaume Apollinaire).

Além da dinâmica entre os sistemas periféricos e centrais outros fatores, segundo Lefevere, controlam o sistema literário, sendo classificados como internos e externos. O controle interno é exercido pelos profissionais da área (escritores, professores de literatura, críticos, tradutores etc.), que possuem autonomia e status no seu campo particular. O controle externo é

\footnotetext{
4 Segundo Pryzbicien "vários críticos americanos têm atribuído a mudança na produção poética posterior de Bishop à poesia confessional de [Robert] Lowell. Meu ponto de vista é de que foi Carlos Drummond de Andrade, não Lowell, quem a ensinou a balancear temas intensamente pessoais com um tom irônico em seus poemas sobre memória". ["Several American critics attribute the shift in Bishop's late poetic production to Lowell's confessional poetry. My view is that it was Carlos Drummond de Andrade, not Lowell, who taught her to balance intensely personal themes with an ironical tone in her memory poems" (PRYZBYCIEN 1998: 103).
} 
Batista, E. L. A. O. - Poéticas em conflito: a literatura brasileira traduzida por Elizabeth Bishop no contexto das trocas culturais Brasil x EUA

exercido pela patronagem, que deve ser entendida, segundo Lefevere, como "os poderes (pessoas, instituições) que podem promover ou obstruir a leitura, escrita e reescrita da literatura" (LefeVERE 1992: 15). A patronagem se interessa mais pela ideologia do que pela poética e delega competência aos profissionais quando se trata de questões relativas à segunda esfera. A patronagem pode ser exercida tanto por indivíduos, como os mecenas, como por grupos de pessoas ou instituições, como as fundações Rockfeller, Ford, Fullbright e a editora Time Life, que patrocinaram projetos de Bishop sobre 0 Brasil. Os patronos não são os responsáveis pela reescrita, mas por sua publicação e divulgação, atuando de forma direta na seleção das reescritas a alcançarem o grande público. De uma forma geral, os patronos estão ligados à ideologia dominante, representada nos quadros dirigentes das instituições de ensino, revistas, jornais etc. A patronagem dá o tom ideológico às reescritas, uma vez que, segundo Lefevere, "a aceitação da patronagem implica a integração em um certo grupo de apoio e seu estilo de vida" (LefEVERE 1992: 14).

Acreditamos que as traduções realizadas por Bishop tenham sido movidas antes de tudo por seu interesse pelos autores escolhidos e por suas obras. Mas, a oportunidade de publicá-las e de obter um retorno financeiro está diretamente ligada ao amplo mercado que se abriu para estudos acadêmicos, ficção, artigos, livros de viagem, matérias jornalísticas, documentários e outras representações sobre a América Latina, fomentado pela política cultural norte-americana para o hemisfério durante a Guerra Fria. Esse mercado era financiado antes de tudo pelo governo norteamericano, que atuava em conjunção com instituições privadas. A patronagem do governo e das instituições com as quais cooperava parece não ter oferecido a Bishop grandes embaraços, como ofereceram ao cineasta Orson Welles, cujo documentário sobre o Brasil (It's all true, rodado em 1942), patrocinado pelo Departamento de Estado norte-americano, teve seu projeto cancelado a meio caminho por não se adequar à agenda política de sua patronagem. 0 
Batista, E. L. A. O. - Poéticas em conflito: a literatura brasileira traduzida por Elizabeth Bishop no contexto das trocas culturais Brasil x EUA

Departamento de Estado não estava preocupado em conhecer a realidade do povo brasileiro (através de um documentário que mostrava a vida de um jangadeiro em Fortaleza e de um negro em uma favela do Rio de Janeiro), mas queria apenas um motivo para reforçar seus laços de influência, objetivo melhor realizado pelo longa-metragem de Walt Disney Alô amigos, lançado no ano de 1942, e que apresenta o Brasil estereotipado do samba, do carioca malandro e da baiana brejeira.

Bishop parece ter professado a mesma ideologia de sua patronagem, as grandes publicações norte-americanas sobre literatura, como The New Yorker, The New York Times, Partisan Review, e outras, nas quais suas obras eram presença frequente e cujos diretores muitas vezes eram seus amigos pessoais. Segundo Lefevere, os reescritores são delegados pelos patronos para manterem o sistema literário alinhado com sua própria ideologia. A aceitação da patronagem implica que os reescritores trabalhem dentro dos parâmetros colocados por seus patronos. A posição de centralidade de Bishop no sistema literário norte-americano sugere seu alinhamento com a ideologia dominante e pode ser comprovado por sua postura conservadora (tanto literária quanto politicamente) e pouco crítica ao status quo.

A interferência da patronagem no trabalho de Bishop pode ser melhor apreciada no episódio do volume Brazil, encomendado pela Time-Life para a coleção Biblioteca Internacional. Em carta de 1961, Bishop relata o projeto à sua tia Grace:

A revista Life me pediu para escrever o texto de um livrinho sobre o Brasil. Eles publicam uma série destes livros - cada um sobre um país diferente. 0 mais provável é que ninguém leia o texto, mesmo, e só veja as fotos, que normalmente são maravilhosas [...]. Mas escrever esse tipo de coisa é difícil para mim, e tenho que cobrir todo o país história, economia, geografia, artes, esportes - tudo, ainda que de modo superficial. Porém vou ser bem paga [...]. Não gosto da revista e não gosto deles [...] - mas quero ganhar dinheiro - e a esta altura de fato sei muita coisa sobre o Brasil, querendo ou não (BISHOP 1995: 434). 
Batista, E. L. A. O. - Poéticas em conflito: a literatura brasileira traduzida por Elizabeth Bishop no contexto das trocas culturais Brasil x EUA

Na finalização do livro, Bishop se desentendeu seriamente com os editores, que sugeriram diversas alterações ao seu projeto. É o que declara em carta de 1962, quando o livro foi publicado - "o livro Brazil é mesmo um horror; tem algumas frases que simplesmente não fazem sentido. E pelo menos as fotos podiam ser boas. Se você se der ao trabalho de ler o livro, é possível que encontre aqui e ali algum vestígio do que eu pretendia dizer originariamente" (BISHOP 1995: 443). O convite de Bishop para assinar o livro devia-se antes de tudo ao seu status de escritora reconhecida (já havia conquistado o prêmio Pullitzer) e de "conhecedora" do Brasil. Nesse sentido seu nome na capa do livro serviria como uma estratégia de marketing com vistas a vendas lucrativas. Os desentendimentos entre Bishop e os editores parecem ter se dado pela imposição de um modelo padronizado que Bishop não queria seguir. Não houve exatamente um choque ideológico, mas as preocupações de Bishop parecem ter se dirigido mais aos aspectos estéticos do livro, como declara em carta de 1962: "acho que o pior de tudo é como eles vulgarizam os títulos de capítulos e legendas" (Ibidem: 714). Completa:

[...] as fotos são mesmo o mais imperdoável de tudo - o que não falta é material, tem coisas maravilhosas [...]. Eles receberam minhas ideias com entusiasmo, só que não tomaram nenhuma iniciativa. [...] Imagine um Rio de J aneiro sem nenhum pássaro, nenhum bicho, nenhuma flor. E existem fotos maravilhosas de índios, suas casas, seus adereços, suas danças, etc. - não saiu nada (BISHOP 1995: 714-15).

Aparentemente a imagem do Brasil de Bishop não entrou em acordo com a imagem pretendida pela Time-Life. Bishop tentou projetar no livro uma imagem que se concentrava naqueles aspectos que considerava naturais e originais e que entravam em concordância com sua imagem do país formada pelo dualismo "natureza exuberante" e "sociedade primitiva e autêntica". Como declara na mesma carta de 1962 - "eu insisti que devia haver pelo menos uma página de fotos de animais [... - escrevi duas ou três páginas boas sobre a natureza - o efeito dela sobre a linguagem - bichos de estimação - 
Batista, E. L. A. O. - Poéticas em conflito: a literatura brasileira traduzida por Elizabeth Bishop no contexto das trocas culturais Brasil x EUA

pássaros de gaiola etc. - cortaram tudo" (BISHOP 1996: 716). Os editores, ao contrário, pretendiam divulgar uma imagem do Brasil desenvolvimentista, que havia definitivamente entrado na sua etapa industrial com o governo de Juscelino Kubitschek, no final da década de 1950. Bishop critica a tendenciosidade dos editores que, segundo ela, estavam mais interessados em apregoar as benesses da industrialização, criando uma imagem do país onde "dão a entender que a solução de todos os problemas da vida é a "industrialização'" (BISHOP 1996: 715). É nesse sentido que os títulos "sugestivos" de Bishop para os capítulos do livro, como, "Cap. 2 A terra do pau-brasil, Cap. 5 Animal, vegetal, mineral, Cap.6 As artes espontâneas", são substituídos por títulos como "Esplendores modernistas de uma capital na fronteira". Na verdade Bishop não se opunha à ideologia de sua patronagem, como declara na mesma carta - "não há dúvida de que a industrialização é a única coisa que pode salvar o Brasil, seja boa ou má, mas a maneira como eles colocam a coisa [...]" (BISHOP 1996: 715), ela apenas apresentava uma imagem mais idealizada e estetizada do país. Como nota Lefevere, a patronagem interessa-se principalmente pelos fatores ideológicos e econômicos. Quando há um confronto entre um desses fatores e o poético, os primeiros tendem a vencer o segundo. 0 resultado é que Bishop renegou o livro (costumava corrigir pessoalmente os exemplares que encontrava nas casas dos amigos), que foi publicado como uma coedição entre a poeta e os editores da TimeLife.

Outro viajante norte-americano que visitou o Brasil na década de 1950 foi o escritor J ohn dos Passos, que esteve aqui em 1958 visitando Brasília para escrever um artigo para a revista Reader's Digest a convite do Departamento de Estado dos EUA, e que visitou Bishop e sua amiga Lota de Macedo Soares em Samambaia. Além do artigo, dos Passos acabou publicando também um livro sobre o Brasil, que Bishop considerou "uma porcaria tão grande que nem consegui ler, e muito superficial" (BISHOP 1996: 463). Intitulado "Brasília, uma capital surge no sertão", o artigo de dos Passos que inicialmente o trouxe ao 
Batista, E. L. A. O. - Poéticas em conflito: a literatura brasileira traduzida por Elizabeth Bishop no contexto das trocas culturais Brasil x EUA

país parece seguir o estilo dos editores da Time-Life, retomando o discurso do "país do futuro", no qual os imigrantes de Brasília são comparados aos "colonos americanos do oeste dos EUA ha cem anos atrás" (Dos PAssos 1960: 19). O texto é marcado pelo ufanismo que vangloria as dimensões do país e do empreendimento da construção de Brasília, e seu tom geral pode ser entrevisto no período com que o texto se inicia: "Num planalto do sertão, a mais de 1.000 quilômetros do mar, a maior nação da América do Sul e 0 quarto país do mundo em superfície está terminando uma nova capital" (Dos PAssos 1960: 15). 0 artigo de dos Passos apresenta o mesmo tipo de imagem do país presente nas intenções dos editores da Time-Life de Brazil, apregoando sua capacidade de desenvolvimento e as vantagens que 0 processo de industrialização trará ao país, integrando-o ao capitalismo ocidental.

Além de financiar o trabalho dos reescritores, a patronagem é principalmente responsável pela divulgação das reescritas. Foi através do projeto da Wesleyan University de editar uma antologia de poesia brasileira que Bishop pôde aumentar o público leitor de suas traduções, até então restrito aos leitores especializados dos jornais e revistas literárias nas quais as havia publicado originalmente. 0 interesse da universidade em patrocinar uma antologia brasileira parece ter sido uma resposta à demanda criada pelos estudos brasilianistas e por todo o interesse que se formou sobre a América Latina no período. Como nos alerta Lefevere, as antologias são publicadas quando a cultura em questão ocupa um papel de destaque.

Segundo Lefevere, as antologias são os tipos mais potenciais de reescritas, por apresentarem em um volume três processos de manipulação: a seleção, a tradução e a crítica. Isso decorre em razão das antologias se constituírem de uma seleção de textos, traduzidos (se estrangeiros) e apresentados por introduções e prefácios de caráter crítico sobre as obras editadas. Cada um desses processos representa uma reescrita, que pode ser realizada pela mesma pessoa (no caso de Bishop), ou por três diferentes 
Batista, E. L. A. O. - Poéticas em conflito: a literatura brasileira traduzida por Elizabeth Bishop no contexto das trocas culturais Brasil x EUA

instâncias (o tradutor, o editor e o prefaciador). A capacidade das antologias de criarem imagens de uma literatura é grande devido ao seu objetivo representativo e introdutório de uma literatura estrangeira ou de um determinado tema literário. Se levarmos em conta que as antologias são muitas vezes utilizadas como textos de consulta em cursos de literatura, 0 poder de que falamos se potencializa ainda mais, por tornar-se referência básica para estudantes que muitas vezes se tornarão posteriores retransmissores daquele conhecimento - e daquela imagem. Como nota Lefevere, o sistema educacional é um dos principais responsáveis pela canonização e manutenção da posição canônica dos textos, e que por sua vez age em sintonia com as editoras, formando um ciclo de produção e consumo. Para Lefevere, a canonização de obras literárias

\footnotetext{
[...] encontrou seu mais impressionante - e rendoso - monumento na publicação da híbrida cristalização da cooperação estreita e lucrativa entre editoras e instituições superiores de ensino: a antologia introdutória, que oferece uma seção cruzada de textos canonizados prefaciados por uma curta exposição da poética que garantiu sua canonização (LeFEVERE 1992: 22).
}

A antologia é um importante elemento canonizador, tornando as obras antologizadas atemporais e inquestionáveis, promovendo sua canonização em níveis transnacionais e transculturais. A Introdução de Bishop à antologia publicada pela Wesleyan University apresenta uma imagem pouco positiva de nossa literatura, considerada como um reflexo atrasado da literatura europeia e dotada de características linguísticas problemáticas. Essa visão decorre de vários fatores, entre os quais o confronto entre as diferentes poéticas dos dois sistemas literários envolvidos. A poética seria, para Lefevere, o segundo fator a atuar sobre as reescritas, junto à patronagem.

0 confronto entre duas diferentes concepções poéticas parece estar por trás de certos desentendimentos de Bishop com relação à nossa cultura e literatura, o que pode ser entrevisto em primeira mão pela oposição que ela 
Batista, E. L. A. O. - Poéticas em conflito: a literatura brasileira traduzida por Elizabeth Bishop no contexto das trocas culturais Brasil x EUA

estabelece entre sua origem anglo-saxônica e a origem latina da cultura brasileira (em especial nossa filiação à cultura francesa), e que revela uma divergência entre as poéticas dos dois sistemas literários envolvidos. Essa oposição pode ser vista nas cartas onde relata suas discussões com os intelectuais brasileiros: "[...] não conhecem nossos críticos em absoluto, limitam-se a repetir as ideias de um punhado de franceses católicos antiamericanos, que também não sabem muita coisa sobre os Estados Unidos e os escritores americanos - ou só conhecem muito pouco" (BISHOP 1997: 356), e na Introdução à antologia, onde se irrita com a filiação brasileira à poética francesa, considerada ultrapassada: "[...] aparentemente os poetas são influenciados, ou talvez simplesmente copiem, a norma francesa" (BISHOP 1972: XVI). Isso em um momento em que a influência cultural norteamericana sobre o país começa a se estabelecer, como nota a própria Bishop na Introdução da Antologia:

[...] a literatura e a filosofia francesa foram, e permaneceram, até muito recentemente, as influências mais fortes no pensamento e na literatura brasileira. Elas são ainda de importância fundamental, mas a prosa e a poesia inglesa, e principalmente, a norte-americana, estão se tornando rapidamente conhecidas. 0 inglês está agora se tornando a língua estrangeira mais na moda e mais importante (BISHOP 1972: XVIII).

A disputa entre as duas metrópoles pelo mercado cultural brasileiro (que passa a ser ganha pelos EUA exatamente a partir da época da vinda de Bishop ao Brasil) nos confirma a situação periférica do sistema literário brasileiro naquele momento, e explica em parte a antipatia de Bishop para com as influências francesas em nossa poética.

Além da ascendência francesa, nossa literatura possui outras características específicas que foram motivos de estranhamento para Bishop e que entraram em choque com sua poética, diretamente filiada ao alto modernismo norte-americano. Essa poética era representada pelo nome de T. S. Eliot, um de seus maiores defensores, seja através de seus poemas, seja 
Batista, E. L. A. O. - Poéticas em conflito: a literatura brasileira traduzida por Elizabeth Bishop no contexto das trocas culturais Brasil x EUA

através de sua obra crítica e teórica, que, vinculada ao New Criticism, pregava a imanência da obra literária e o seu valor autônomo como objeto artístico (recusando-se a reconhecer as origens ideológicas dos valores críticos). O discurso do modernismo literário representado pelo pensamento de Eliot apresentava-se como apolítico, rompendo as fronteiras nacionais através do trânsito de seus principais participantes entre a Inglaterra e a América. Como aponta Stan Smith, em The origins of modernism (1994), “o modernismo enquanto operação ideológica recusa suas origens nas políticas de gênero, classe e nacional de seu momento [...] situando-se antes e depois, mas nunca 'no' reino do Evento histórico" (SMITH 1994: 19). No modernismo norteamericano essas esferas (gênero, classe, nacional) são obliteradas, e seu discurso paira acima delas, produzindo obras que pretendem refletir valores universais e humanistas, que transcendem o tempo. Em decorrência disso muitos críticos contrastam o radicalismo artístico trazido pelo movimento ao seu reacionarismo social e político, representado tanto pela defesa do fascismo feita por Ezra Pound, quanto pela tríade eliotiana do classicismo, anglicanismo e monarquismo.

Enquanto o modernismo em língua inglesa se distinguiu por um caráter aristocrático, o brasileiro, por sua vez, procurou apresentar um viés mais democrático, inspirando-se na linguagem coloquial e parodiando a cultura popular. Apesar de ter se constituído como um movimento elitizado (patrocinado pela elite e a ela dirigido, no sentido de criar para as classes dominantes nacionais uma imagem do país que fosse mais atualizada em relação aos modelos europeus) ${ }^{5}$, as inspirações populares impediram que 0 movimento brasileiro alcançasse 0 caráter erudito apresentado pelo modernismo norte-americano. Na tentativa de definir nosso Modernismo, Wilson Martins consegue sintetizar (apesar de aparentemente não ser esta sua

\footnotetext{
${ }^{5}$ Segundo Wilson Martins “[...] não só o Modernismo como todas as revoltas militares e institucionais, até 1932, foram revoluções burguesas, não só porque foi afinal a burguesia que delas se beneficiou, mas, ainda, porque se originaram numa ideologia burguesa e desejavam a consolidação dos ideais burgueses de vida" (MARTINS 1969: 131).
} 
Batista, E. L. A. O. - Poéticas em conflito: a literatura brasileira traduzida por Elizabeth Bishop no contexto das trocas culturais Brasil x EUA

intenção) em uma sentença todas as antinomias existentes entre os movimentos brasileiro e estadunidense: "o Modernismo [brasileiro] opta pelo rumo nacionalista contra o cosmopolitismo, primitivo contra o artifício, sociológico contra o psicológico, folclórico contra o literário, e político contra o gratuito" (MARTINS 1969: 92). Ou seja, enquanto nosso movimento se definia pela forte marca local, como símbolo do nacional, através do apelo popular do primitivo e do folclórico, apresentando ainda uma proposta social (mesmo que esta venha a se esgotar em seu discurso), o movimento norte-americano se pautava por uma erudição literária e linguística, em que uma suposta gratuidade da arte Ihe garantia um espaço acima das esferas políticas e sociais.

Em um certo sentido, portanto, pode-se dizer que o nosso modernismo diferenciou-se do norte-americano, por trazer um viés social e político que só seria incorporado ao segundo posteriormente. Como afirma Eliana Bastos, em sua comparação da Semana de Arte Moderna brasileira de 1922, com o Armory Show norte-americano, realizado em 1917, "a noção de nacionalismo, claramente definida como um valor, só aparece um tanto tardiamente no modernismo americano" (BASTOS 1991: 62). No Brasil, por exemplo, a incorporação da imagem do negro e do mestiço na literatura canônica se dará de forma mais positiva (ainda que questionável) logo a partir do movimento modernista de 1922, que teve um de seus marcos no lançamento de Juca Mulato de Menotti Del Picchia, ou nos poemas de Oswald de Andrade, enquanto na literatura norte-americana, esse tema só será integrado ao cânone a partir das décadas de 1950-60, como resposta aos movimentos sociais dos negros ${ }^{6}$. Como sugere ainda Bastos, "devido ao preconceito racial e ao princípio da não miscigenação, só muito mais tarde a cultura do negro veio a ser incorporada como um valor, com exceção do jazz, mesmo assim só

\footnotetext{
${ }^{6}$ Excetuando-se A Cabana do pai Tomás que, como os poemas de Castro Alves, surgiu para fortalecer a propaganda abolicionista. E o movimento Harlem Renaissance, que eclodiu entre os anos 1920-1930.
} 
Batista, E. L. A. O. - Poéticas em conflito: a literatura brasileira traduzida por Elizabeth Bishop no contexto das trocas culturais Brasil x EUA

aceito como expressão de cultura popular" (BASTOS, 1991: 63). É só a partir dessa época que a literatura norte-americana se abriu para as questões sociais, incorporando não só a problemática do negro, mas da mulher e outras "minorias", seja através do movimento Beat, profundamente questionador do status quo norte-americano, quanto através dos movimentos sociais setorizados, mudanças das quais Bishop manteve-se à parte ${ }^{7}$.

Por outro lado, o propalado viés apolítico do discurso modernista em língua inglesa revela, obviamente, uma posição política, como atesta Fredric Jameson, em Modernism and imperialism: "um dos estereótipos mais comumente mantidos sobre o modernismo tem sido em geral, é claro, o de seu caráter apolítico, [...] sua crescente subjetificação e psicologização introspectiva e, ainda, seu esteticismo e compromisso ideológico ao supremo valor da agora autônoma Arte" (EAGLETON, J AMESON, SAID 1990: 45). O suposto caráter apolítico do modernismo representava na verdade uma ausência de discussão política no discurso literário e, portanto, a aceitação do status quo, daí seu conservadorismo. A asserção de determinados valores (estéticos, intelectuais e psicológicos) como universais, reflete uma atitude política etnocêntrica que é questionada por J oan Rosalie Dassin, e pode ser preciosa no entendimento da avaliação feita por Bishop sobre nossa literatura - "a proclamada independência entre política e cultura disfarça uma tendência elitista que se torna bem óbvia quando o crítico norte-americano branco aborda a arte e a literatura dos países chamados 'subdesenvolvidos', aplicando 'objetividade' e 'distanciamento intelectual' como valores universais" (DASSIN 1978: 26).

\footnotetext{
${ }^{7}$ Pode-se dizer que já a partir da década de 1930 surge uma preocupação social na literatura norte-americana, especialmente em decorrência da depressão gerada pelo crash da bolsa de 1929, incorporando temas do marxismo e do socialismo, mas apesar disso a poética representada pelo New Criticism e por Eliot permaneceu em desenvolvimento e vigor até praticamente a II Guerra Mundial. Com relação a esse tema, Bishop declara em entrevista de 1978 - "mas eu não fui tão afetada pela Depressão como alguns de meus contemporâneos; não tanto quanto meus amigos disseram que eu deveria ter sido. Eu sempre estive mais interessada em coisas visuais do que em política" (BISHOP 1996: 113).
} 
Batista, E. L. A. O. - Poéticas em conflito: a literatura brasileira traduzida por Elizabeth Bishop no contexto das trocas culturais Brasil x EUA

É perfeitamente compreensível que imersa na poética modernista norte-americana Bishop tenha estranhado tanto nossa literatura, que tem como uma de suas especificidades exatamente o engajamento em uma reflexão nacional. Como coloca Antonio Candido "poucas [literaturas] têm sido tão conscientes de sua função histórica" como a brasileira (CANDIDO 1981: 26). Posição que se confronta diretamente com a abordagem imanentista pregada por Eliot. Além da pretensa atemporalidade e universalidade, a poética do modernismo norte-americano trazia ainda outro fator de choque com a literatura brasileira: a "teoria impessoal da poesia", de Eliot, apresentada em seu artigo "Tradição e talento individual". Nesse artigo, Eliot, ao explicar a tarefa do poeta, utiliza-se da imagem do filamento de platina que atua como catalisador em um processo químico, onde a mistura de dois gases forma o ácido sulfúrico, sem que o filamento altere-se ou deixe resíduos no produto formado: "[...] a mente do poeta é o fragmento de platina. Ela pode, parcial ou exclusivamente, atuar sobre a experiência do próprio homem, mas, quanto mais perfeito for 0 artista, mais inteiramente estará separado nele o homem que sofre e a mente que cria [... ]" (ELIOT 1989: 42). Segundo a teoria de Eliot, o poeta não deve deixar sua marca pessoal na obra. A obra deve falar por si própria, e não pela voz do seu autor. A filiação de Bishop a essa poética, que prega uma literatura pretensamente desistoricizada e impessoal, é percebida em sua obra, marcada por uma proposta esteticista e pela impessoalidade e aparente ausência de uma voz. Ela mesma declarava: "politicamente, eu me considero uma socialista, mas desaprovo uma escrita socialmente engajada. Eu defendia T. S. Eliot quando todos estavam falando sobre James T. Farrel" (BISHOP 1996: 22), ou ainda quando declara que "poesia não deveria ser usada como veículo de nenhuma filosofia pessoal" (Ibidem: 104). É em função dessa poética, professada por Eliot e seguida por Bishop, que ela criticava tenazmente a literatura confessional (por ser pessoal demais) e a literatura feminista ${ }^{8}$ (por ser social

\footnotetext{
${ }^{8}$ Bishop se recusava terminantemente a participar de antologias de mulheres escritoras e
} 
Batista, E. L. A. O. - Poéticas em conflito: a literatura brasileira traduzida por Elizabeth Bishop no contexto das trocas culturais Brasil x EUA

demais). É também em função dessa visão impessoal da poesia que seu senso estético vai entrar em choque com a poética brasileira, marcada tanto pelo viés histórico-social como por um sentimentalismo e lirismo que the pareceram por demais pessoais. Esses dois elementos (pessoalidade e historicidade) são considerados por Bishop como marcas de uma prémodernidade, atribuindo à nossa literatura a permanência de valores românticos, como declara em carta: "amor e 'comentário social' é mais ou menos o estágio em que todos estão aqui [... ]" (BISHOP 1995: 720). Ou quando responde ao repórter sobre o que quis dizer ao afirmar que as literaturas brasileira e norte-americana seguiram por caminhos diferentes:

O que aconteceu com Eliot e Pound logo em 1910 - o modernismo. A poesia brasileira é muito mais formal que a nossa - ela é mais distante do popular. É verdade que eles tiveram um movimento modernista em 1922, liderado por Mário de Andrade e outros. Mas eles ainda não escrevem do modo que falam. E eu suponho que eles nunca escaparam do romantismo (BISHOP 1996: 19) (grifo meu).

A crítica à presença incômoda de valores românticos em nossa cultura moderna não é exclusiva de Bishop e, além de refletir um descompasso entre poéticas, aponta para uma característica de nossa cultura. É o que questiona Paulo Prado em Retrato do Brasil lançado em 1927, em pleno efervescer do movimento modernista, e que inclui o romantismo como um dos males brasileiros. Segundo ele

[...] basta abrir um jornal, ouvir uma conferência, ou folhear o último livro publicado para se descobrirem, latentes, inconscientes, mas indeléveis, os traços sintomáticos da infecção romântica. Apesar da crescente influência modernista [...] nossa indolência primária ainda se compraz no boleio das frases, na sonoridade dos palavrões, nas "chaves de ouro" (PRADO 1997: 180).

odiava "crítica de gênero", pois não aceitava a ideia de haver algo como uma literatura produzida por mulheres, havia apenas a "alta literatura", no sentido imanentista pregado por Eliot - acima das esferas de gênero, política, classe, etc. A esse respeito ver entrevista a Eileen Farley de 1974 (BISHOP 1996: 54). 
Batista, E. L. A. O. - Poéticas em conflito: a literatura brasileira traduzida por Elizabeth Bishop no contexto das trocas culturais Brasil x EUA

Comentando Prado, Wilson Martins (1969), já na segunda metade do século XX e refletindo sobre o modernismo, concorda, em termos, com 0 autor, diz ele - "não é o romantismo que concorre como um elemento na constituição da psicologia brasileira, é esta última que, sendo o que é, resultaria forçosamente numa literatura e num temperamento de fortes características românticas" (MARTINS 1969: 183). Ambos concordam com a presença do romantismo na sociedade brasileira, impregnando suas manifestações mais diversas, mas enquanto o primeiro o vê como um mal que invadiu o país e "deformou insidiosamente o organismo social" (PRADo 1997: 179), o segundo vê sua presença na própria constituição psicológica do povo brasileiro, não sendo, portanto, um mal que o invade, mas que the é próprio. Ao apontar nossa tendência romântica, Bishop não apenas contrapõe sua própria poética à nossa (uma vez que a poética de Eliot apresentava-se como essencialmente antirromântica e antilírica), mas parece ter acertado no calcanhar de Aquiles da literatura brasileira ${ }^{9}$. A presença romântica em nossos escritores, que Bishop critica, também é alvo de Martins, que no seu estudo sobre o modernismo, ao abordar, por exemplo, Manuel Bandeira, questiona o que Paulo Prado chamou de "indolência primária": "nem tudo, em Manuel Bandeira, é Manuel Bandeira: muitas vezes ele é apenas o poeta 'bonzinho' de que falava Mário de Andrade" (MARTINS 1969: 210).

Apesar de muito admirado, Manuel Bandeira foi um dos principais alvos das críticas de Bishop, que o considerava o estereótipo do poeta brasileiro. A figura e o papel do poeta em nossa cultura, representado por Bandeira, pode ser considerado outro ponto de "obstrução" na relação de Bishop com nossa literatura, em função da contraposição de diferentes "papéis culturais" (cultural scripts), termo usado por Lefevere para definir "o padrão aceitável de comportamento de pessoas que preenchem certos papéis em uma certa cultura" (LefEVERE 1992: 92). A ampla difusão da prática poética no Brasil por

\footnotetext{
${ }^{9}$ Pelo menos até a metade do século XX.
} 
Batista, E. L. A. O. - Poéticas em conflito: a literatura brasileira traduzida por Elizabeth Bishop no contexto das trocas culturais Brasil x EUA

vezes era considerada positiva por Bishop, devido à alta consideração dada aos poetas; mas por outro lado a desagradava, por gerar uma massa indiscriminada de poetas bissextos que produziam poesia de baixa ou nenhuma qualidade (em suas palavras), o que ia contra sua concepção do poeta como um profissional especializado. Incomodava-se também com a atitude do poeta brasileiro, considerado acomodado e, após ver uma foto de Bandeira deitado em uma rede, comentou que essa seria a imagem do poeta brasileiro, e o "problema" da literatura brasileira. Ora, a visão de Bishop do papel cultural do poeta está muito mais ligada à imagem do pernóstico Eliot e da reticente Marianne Moore, dedicados profissionais da escrita, representantes de um momento de especialização nos meios literários e acadêmicos nos Estados Unidos. Esse momento foi dominado pelo New Criticism, que como um fenômeno do pós-guerra desenvolveu-se concomitantemente com o surgimento do magistério superior e a institucionalização dos estudos literários enquanto profissão burguesa nos Estados Unidos. Segundo Dassin:

[...] os professores e críticos de literatura, sobretudo, criaram uma ideologia de autossustentação ao exaltarem o empenho humanístico como veículo para a autorrealização e, ao mesmo tempo, postularam uma sociedade pluralista que Ihes permitisse o máximo de liberdade individual como paradigma do ambiente intelectual perfeito. A literatura divorciava-se assim do contexto social [...]. O McCarthismo e a Guerra Fria forçaram a maioria dos intelectuais do sistema a declarar sua obra apolítica [...] Tendo atingido privilégios sociais e econômicos com base na habilidade intelectual ou técnica, os intelectuais tinham que valorizar essa mesma habilidade como um fim em si mesmo (DASSIN 1978: 130).

Podemos averiguar essa situação de profissionalização do intelectual através da extensa relação de bolsas e prêmios que Bishop recebeu e que a ajudaram a manter-se financeiramente (além, é claro, dos valores recebidos por seus livros publicados, assim como artigos e entrevistas em jornais e revistas), e que incluem, entre outros, o Prêmio Shelley Memorial, de 1952, o 
Batista, E. L. A. O. - Poéticas em conflito: a literatura brasileira traduzida por Elizabeth Bishop no contexto das trocas culturais Brasil x EUA

Prêmio Pullitzer de poesia de 1956, o Prêmio National Book Award, de 1968, o Prêmio de viagem Amy Lowel, e a bolsa da Academy of American Poets, além de cargos como professora convidada ou poeta visitante de universidades como University of Washington, University of New York, Harvard University e MIT.

O papel cultural do poeta, para Bishop, estava vinculado a uma postura extremamente profissional e erudita, que não entrava em acordo com a imagem do poeta brasileiro displicentemente estendido em uma rede. Bishop recebeu de presente de Bandeira uma rede, mas provavelmente não a definiria como o melhor lugar para trabalhar ${ }^{10}$. Se a obra poética é fruto de um trabalho árduo e meticuloso, como poderia ser realizado naquilo que se considera um símbolo do descanso e relaxamento?

A aplicação de toda a perspectiva representada pelo New Criticism a uma avaliação da literatura latino-americana, incluindo a brasileira, através da transposição do conceito de "objetividade", e de uma crítica formal e estética, é contraproducente, e não ajuda a esclarecer suas especificidades, estando desde seu início fadada ao fracasso. Não é possível desvincular no estudo da literatura latino-americana as esferas política e social, e seria ingenuidade supor que o mesmo não se aplica às outras literaturas, como a própria estadunidense. Segundo essa abordagem formalista, os artistas latinoamericanos seriam realmente modernos apenas quando "contemporâneos", ou "internacionais", não vinculados ao "passado" através do nacionalismo, figurativismo, realismo social e outras tendências consideradas similarmente anacrônicas. Não é, portanto, por puro preconceito, que Bishop tenha criticado tanto nossa literatura. Sua postura é antes de tudo o reflexo do seu modo de pensar e fazer literatura.

\footnotetext{
${ }^{10}$ Em entrevista a Ashley Brown em 1966, ao ser questionada sobre a inspiração da paisagem em sua casa (Samambaia, em Petrópolis), Bishop disse que para trabalhar qualquer poeta deveria preferir "um quarto de hotel completamente vazio de distrações" (BISHOP 1996: 18).
} 


\section{Referências bibliográficas}

BARBOSA, H. G. The virtual image: Brazilian literature in English translation. 1994. 500 f. 2 v. Tese (PhD) Centre for British and Comparative Cultural Studies, University of Warwick.

BASTOS, E. Entre o sucesso e o escândalo. A Semana de 22 e o Armory Show. Campinas: Unicamp, 1991.

BatistA, E. L. A. O. O método de Elizabeth Bishop na tradução de obras brasileiras. Cadernos de Tradução, V. 15, p. 55-68, 2005.

BISHOP, E. BRASIL, Emanuel (Org.). An anthology of twentieth-century Brazilian poetry. Middletown: Wesleyan University, 1972.

. Uma arte. As cartas de Elizabeth Bishop. Org. Roberto Giroux. Trad. Paulo Henriques Brito. São Paulo: Cia. das Letras, 1995.

. Conversations with Elizabeth Bishop. Ed. George Monteiro. Jackson: University Press of Mississipi, 1996.

Brito, P. H. Bishop no Brasil. In: Bishop, Elizabeth. Poemas do Brasil. Sel.Int.Trad.: Paulo Henriques Brito. São Paulo: Cia. das Letras, 1999. p. 9-54.

CANDIDO, A. Formação da literatura brasileira. Belo Horizonte: Itatiaia, 1981.

DASSIN, J. R. Política e poesia em Mário de Andrade. Trad. Antonio Dimas. São Paulo: Duas Cidades, 1978.

PASSOS, J. Brasília, uma capital surge no sertão. In: StOWE, LELAND. . et all. Trinta e cinco janelas para o mundo. [s.t.] São Paulo: Y̌piranga S. A., 1960. p. 14-22.

Eagleton, Terry, Jameson, Fredric, Said, Edward. Nationalism, colonialism and literature. Minneapolis: University of Minnesota, 1990.

ELIOT, T.S. Selected prose. Ed. John Kayward. Middlesex: Peregrine Books, 1963.

Even-Zohar, I. Polysystem Studies. Poetics Today. Tel-Aviv, V 11, N 1, Spring/ 1990.

LEFEVERE, A. Translation, rewriting and the manipulation of literary fame. London: Routledge, 1992.

MARTINS, W. O modernismo (1916-1945). São Paulo: Cultrix, 1969. 
Batista, E. L. A. O. - Poéticas em conflito: a literatura brasileira traduzida por Elizabeth Bishop no contexto das trocas culturais Brasil x EUA

Prado, P. Retrato do Brasil. Ensaio sobre a tristeza brasileira. São Paulo: Cia. das Letras, 1997.

SMITH, S. The origins of modernism. Eliot, Pound, Yeats and the rhetorics of renewal. New York: Harvester Wheatsheaf, 1994.

VENDLER, H. An anthology of twentieth-century Brazilian poetry. New York Times Book Review, J anuary, 7, 1973. 